\title{
Size and shape of ocean margin nematodes: morphological diversity and depth-related patterns
}

\author{
Karline Soetaert $^{1, *}$, Agnes Muthumbi ${ }^{2}$, Carlo Heip ${ }^{1}$ \\ ${ }^{1}$ Netherlands Institute of Ecology, Centre for Estuarine and Marine Ecology, PB 140, 4400 AC Yerseke, The Netherlands \\ ${ }^{2}$ University of Nairobi, Department of Zoology, PO 30197, Nairobi, Kenya
}

\begin{abstract}
We studied the composition and variation of nematode body size as a function of nematode depth in the sediment and water depth at 18 stations, ranging from 137 to $4951 \mathrm{~m}$ depth, along the Galician margin (NE Atlantic). The analysis is based on more than 10000 individuals and demonstrates that nematodes have adapted mainly in response to the vertical changing conditions in the sediment. Nematode length and width are similar in the upper $0.5 \mathrm{~cm}$ of sediment at all stations, but differ greatly as their depth in the sediment increases. The observed trends are consistent with an adaptation to changing oxygen concentrations in the sediments. In lower slope and abyssal plain stations, oxygen decreases gradually until depletion at about $5 \mathrm{~cm}$ depth, and nematode body width decreases concurrently, resulting in higher oxygen absorption efficiency per unit of volume. On the shelf and in the canyons, sediments become anoxic at short distances below the sediment-water interface, and more than $50 \%$ of the nematodes are present in the anoxic part of the sediment. Here, mean nematode length increases as their depth in the sediment increases. This may result in increased mobility, which enables the organisms to migrate between anoxic patches of food and parts of the sediment where oxygen is available and/or the ability to bridge the gap between oxic and anoxic patches with their body. Order of magnitude calculation shows that in shelf sediments, the chemosynthetic bacterial production, which accompanies the oxidation of reduced substances, can not fulfill the feeding requirements of nematodes in the anoxic zone. The different size adaptations with sediment depth in shallow as compared to deep stations combined with deeper penetration of nematodes into the sediment at shallow water depth cause the observed pattern of miniaturization with increasing water depth. We conclude that nematode size distribution is determined by food availability. However, organic matter, as a food source, is not directly responsible, as a limiting resource, but indirectly because its respiration generates reduced conditions in the sediment. Within the smaller size range $(<500 \mu \mathrm{m}$ length), there are 2 clearly distinct morphological types, which, to a certain extent, impart a taxonomic division. Similar findings at other localities suggest that this is a common feature of nematodes from ocean margin areas. One group consists of corpulent nematodes, which are less than 15 times as long as wide; most prominent in this group are members of the order of the Desmoscolecida. The other group contains significantly more slender nematodes and comprises a large variety of nematode taxa. We hypothesize that this duality in nematode design reflects an ecological adaptation designed to meet the conflicting requirements of either increased mobility (slender) or reduced vulnerability to predation (corpulent) at these small sizes.
\end{abstract}

KEY WORDS: Nematodes $\cdot$ Ocean margin $\cdot$ Sediment biogeochemistry $\cdot$ Size-depth hypothesis Resale or republication not permitted without written consent of the publisher

\section{INTRODUCTION}

Ocean margin sediments cover a vast area of the world, from the continental shelf to the deepest abyssal plains, and harbor a variety of environmental con- ditions. As they are separated from the productive euphotic zone, benthic life there relies on organic matter primarily produced elsewhere. The degradation of this organic matter during transport, combined with the offshore gradients in phytoplankton pro- 
ductivity (Wollast 2002), causes the well-documented decrease of sediment organic matter deposition rates as a function of water depth. This decrease is observed both on the global (Lampitt \& Antia 1997, Middelburg et al. 1997, Soetaert et al. 2002) and on the local scale (Rowe et al. 1991, Lohse et al. 1998, Epping et al. 2002). With depth as a proxy for food deposition, the ocean margin is ideal to test the effect of food availability on nematode communities.

Biological studies have demonstrated the presence of a diverse community of benthic fauna along the ocean margin (Gage \& Tyler 1991 and references herein, Heip et al. 2001), and a consistent decrease in benthic biomass with water depth or, more generally, with decreasing food deposition rates (Rowe et al. 1991, Vincx et al. 1994). Variation in food input impacts the size distribution of the benthic fauna as well. In general, large organisms are more prominent at eutrophic sites, whereas smaller organisms become more dominant in oligotrophic environments (Thiel 1975). This is most clearly expressed as a shift towards smaller-sized taxa with increasing water depth (Pfannkuche \& Soltwedel 1998, Flach et al. 1999, 2002, Galeron et al. 2000), although this shift is not always apparent (Sibuet et al. 1989). Within a taxonomic group, there may be a shift towards smaller-sized individuals (Soetaert \& Heip 1989, Gage \& Tyler 1991, Carney et al. 1993) or the reverse trend (Rex \& Etter 1998), or no shift at all (Flach et al. 1999).

The familiar argument explaining miniaturization with depth is that small organisms, with their reduced maintenance costs, are better adapted to food-poor conditions (Thiel 1975). Alternatively, by combining the allometric relationships of food intake and metabolic losses, it can be shown that the optimal size of an organism, i.e. the size at which net energy gain is maximized, decreases as rates of food input decrease (Sebens 1987, Rex \& Etter 1998). Both of these explanations explain miniaturization as a direct effect of the supply of food, where food is viewed as a limiting resource. Especially for small organisms that are in intimate contact with the sediment, one may expect that food can also exert influence on organism size indirectly, via the biogeochemical changes it brings about in the sediment.

Along the ocean margin, free-living nematodes are prominent members of the metazoan meiofauna, the animals within the 30 to $500 \mu \mathrm{m}$ range (Vincx et al. 1994, Soetaert \& Heip 1995, Soltwedel 2000). They often constitute more than $90 \%$ of all metazoa within this size range. As they are easily sampled, extracted and measured, they have proven to be the taxon par excellence documenting the decrease in mean size with water depth (Soetaert \& Heip 1989, Vanaverbeke et al. 1997a) or more specifically, with reduced food input (Soetaert \& Heip 1995, Vanreusel et al. 1995a, Soltwedel et al. 1996, Sommer \& Pfannkuche 2000, Brown et al. 2001).

The evidence that nematodes are influenced, directly or indirectly, by the supply of food is diverse. Total nematode biomass and/or abundance decline with increasing water depth (Soetaert \& Heip 1995, Vanaverbeke et al. 1997b, Sommer \& Pfannkuche 2000, Vanreusel et al. 2000, Soltwedel 2000) or are positively related to food-derived parameters (Tietjen et al. 1989, Soetaert \& Heip 1995, Vanreusel et al. 1995a, Relaxans et al. 1996, Soetaert et al. 1997, Vanhove et al. 1999, Danovaro et al. 2000, Sommer \& Pfannkuche 2000, Brown et al. 2001). Nematode distribution does not seem to be affected by the oxygen concentrations in the overlying water (Levin et al. 1991). Similarly, nematode penetration vertically into the sediment appears to be directly impacted by the food supply and not by the biogeochemical conditions (Soetaert et al. 1997). Notwithstanding the fact that oxygen does not penetrate deeply into the sediments under highflux regimes, nematodes are still found deep in the sediment under these conditions as well (Thiel 1983, Lambshead et al. 1995, Vanreusel et al. 1995b, Moodley et al. 2000) and a substantial fraction of the community can even be found in the anoxic part.

In contrast to this direct control of food on the overall distribution, there is evidence that nematode community structure is controlled by the biogeochemical conditions of the sediment. The only 2 studies in which nematode taxonomic composition was investigated both vertically in the sediment and along the ocean margin have demonstrated more drastic changes in community structure vertically in the sediment compared to along-slope (Soetaert et al. 1995, Vanaverbeke et al. 1997a).

Body size influences many aspects of an animal, such as its life history, physiology, energy requirements, and biotic and abiotic interactions (Peters 1983, Calder 1984). Assuming that similar shapes correspond, to a certain degree, to similar fitness constraints, morphometric characterization becomes a useful descriptor of ecosystems (Schwinghamer 1983). Because of its presumed relationship with diversity and density (Rex \& Etter 1998), there is currently revived interest in the size distribution of invertebrate communities. In this paper, we will describe the morphometry of nematodes, in terms of body length and width, along the Iberian margin and compare that to other ocean margin areas. In addition we will investigate how the nematode morphological landscape alters as a function of environmental conditions, changing with (1) depth in the sediment and (2) bathymetrically. We will test whether the impact of food availability on the size structure of nematodes along the Iberian margin is 
Table 1. Position of stations. Stations located in the canyon in italics; stations located on the seamount in bold. Dates given as $\mathrm{dd} / \mathrm{mm} / \mathrm{yy}$

\begin{tabular}{|c|c|c|c|c|}
\hline Station & $\begin{array}{l}\text { Sampling } \\
\text { date }\end{array}$ & $\begin{array}{l}\text { Depth } \\
\text { (m) }\end{array}$ & $\begin{array}{c}\text { Position } \\
\text { N }\end{array}$ & $\begin{array}{c}\text { Position } \\
\text { W }\end{array}$ \\
\hline \multicolumn{5}{|l|}{ La Coruña } \\
\hline $\mathrm{CO}$ & $28 / 06 / 97$ & 175 & $43^{\circ} 40.9^{\prime}$ & $8^{\circ} 37.2^{\prime}$ \\
\hline C36 & 01/07/97 & 1522 & $43^{\circ} 40.9^{\prime}$ & $9^{\circ} 26.8^{\prime}$ \\
\hline $\mathrm{C} 41$ & 02/07/97 & 2200 & $43^{\circ} 45.4^{\prime}$ & $9^{\circ} 32.8^{\prime}$ \\
\hline C59 & 04/07/97 & 4909 & $44^{\circ} 00.6^{\prime}$ & $9^{\circ} 54.1^{\prime}$ \\
\hline C125 & $30 / 05 / 98$ & 4951 & $44^{\circ} 10.0^{\prime}$ & $11^{\circ} 09.9^{\prime}$ \\
\hline \multicolumn{5}{|l|}{ Vigo } \\
\hline G0 & $12 / 07 / 97$ & 153 & $42^{\circ} 39.8^{\prime}$ & $9^{\circ} 28.2^{\prime}$ \\
\hline G30 & $11 / 07 / 97$ & 2625 & $42^{\circ} 40.0^{\prime}$ & $10^{\circ} 10.0^{\prime}$ \\
\hline G56 & $09 / 07 / 97$ & 2373 & $42^{\circ} 39.9^{\prime}$ & $10^{\circ} 44.0^{\prime}$ \\
\hline G85 & 08/07/97 & 1794 & $42^{\circ} 40.1^{\prime}$ & $11^{\circ} 22.1^{\prime}$ \\
\hline G100 & 07/07/97 & 764 & $42^{\circ} 44.9^{\prime}$ & $11^{\circ} 44.2^{\prime}$ \\
\hline G25 & 07/06/98 & 2270 & $42^{\circ} 38.2^{\prime}$ & $10^{\circ} 02.5^{\prime}$ \\
\hline \multicolumn{5}{|c|}{ Intermediate } \\
\hline CG & 04/06/98 & 3800 & $43^{\circ} 11.5^{\prime}$ & $10^{\circ} 37.0^{\prime}$ \\
\hline \multicolumn{5}{|c|}{ Nazare Canyon } \\
\hline PE12can & $22 / 05 / 99$ & 344 & $39^{\circ} 38.9^{\prime}$ & $9^{\circ} 14.7^{\prime}$ \\
\hline PE13par & $22 / 05 / 99$ & 137 & $39^{\circ} 38.5^{\prime}$ & $9^{\circ} 20.0^{\prime}$ \\
\hline PE14can & $25 / 05 / 99$ & 3292 & $39^{\circ} 30.7^{\prime}$ & $9^{\circ} 50.0^{\prime}$ \\
\hline PE15par & 24/05/99 & 397 & $39^{\circ} 35.0^{\prime}$ & $9^{\circ} 36.5^{\prime}$ \\
\hline PE17can & 26/05/99 & 4323 & $39^{\circ} 35.7^{\prime}$ & $10^{\circ} 17.5^{\prime}$ \\
\hline
\end{tabular}

Vigo that included a seamount, and 1 transect that included the Nazare Canyon. Samples were taken in June-July 1997, in May-June 1998, and in May 1999 (Fig. 1). The stations covered a water depth from $153 \mathrm{~m}$ to $4951 \mathrm{~m}$. The geographical positions of the stations, date of sampling and water depth are listed in Table 1 . The samples were taken with a box corer, 30 or $50 \mathrm{~cm}$ in diameter, or with a multicorer. Two cores of $10 \mathrm{~cm}$ per station were sliced in layers of $5 \mathrm{~mm}$ thickness for the upper $2 \mathrm{~cm}$ and $10 \mathrm{~mm}$ thickness to $5 \mathrm{~cm}$ depth; the sediment layer from 5 to $10 \mathrm{~cm}$ depth was kept as such. In May 1999, the surface sampled was $30 \mathrm{~cm}^{2}$ instead of $10 \mathrm{~cm}^{2}$. Samples were stored in $4 \%$ formaldehyde. Meiofaunal organisms retained on a $32 \mu \mathrm{m}$ sieve were extracted from the sediment by centrifugation with Ludox (Heip et al. 1985) and colored with Rose Bengal. All organisms were counted. For 1 replicate, at most 120 nematodes from each sediment slice were picked out at random and mounted on glycerin slides. The stage and, for adults, the gender of each nematode was assessed under a microscope. Nematode length (excluding filiform tails) and maximal width were measured using an image analyzer (Quantimet 500+). Nematode dry weight biomass was calculated with Andrassy's formula (Andrassy 1956) assuming a direct (as a limiting resource) or indirect (via biogeochemistry).

This study is part of a large research programme, OMEX II (Ocean Margin EXchange project), which aims to elucidate the importance of ocean margin regions in transferring matter from the shelf to the deep sea and vice versa. In OMEX II the Iberian margin near the Galician coast was investigated. Although the main focus of OMEX was on biogeochemical cycling, the project has also attempted to characterize the biological communities of the sediments in this region. The biomass and higher taxonomic composition of the macro- and meiofauna was described in Flach et al. (2002). The fine-scale structure of the biogeochemical gradients in the sediment and mineralization pathways was the focus of studies performed by Epping et al. (2002) and van der Zee et al. (2001).

\section{MATERIALS AND METHODS}

The benthos was sampled along 3 transects, 1 transect off La Coruña, 1 off

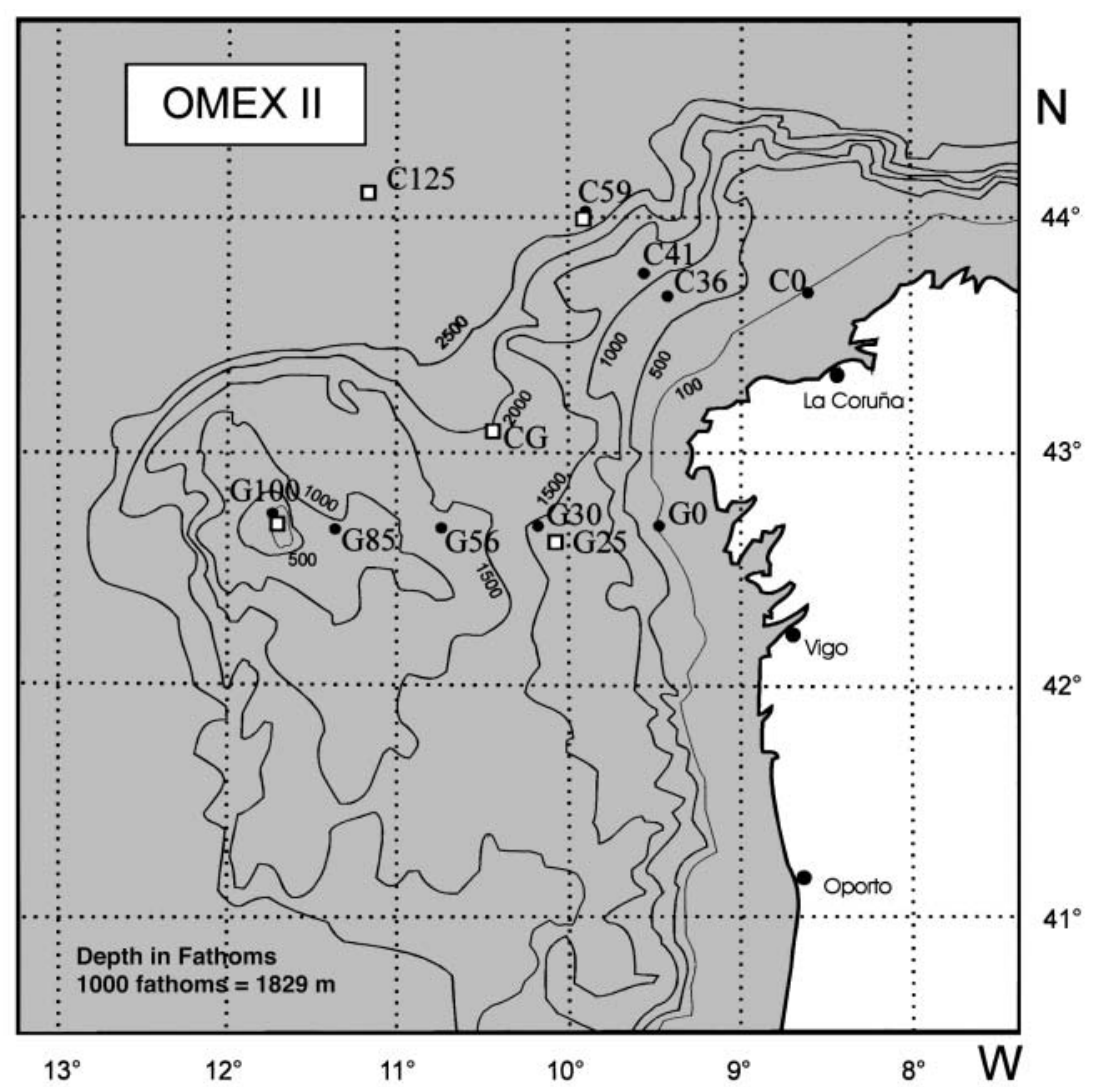

Fig. 1. Location of the sample stations along the Galician margin (NE Atlantic) 
Table 2. Total metazoan meiofauna density (ind. $10 \mathrm{~cm}^{-2}$, integrated over 0 to $10 \mathrm{~cm}$ ), \% nematodes in total metazoan meiofauna, mean individual dry weight (DWT $\mu \mathrm{g})$, \% nematodes in the upper $\mathrm{cm}$

\begin{tabular}{|lrrrrr|}
\hline $\begin{array}{l}\text { Station } \\
\text { ID }\end{array}$ & $\begin{array}{r}\text { Depth } \\
(\mathrm{m})\end{array}$ & $\begin{array}{c}\text { Meiofauna } \\
\text { density }\end{array}$ & $\begin{array}{c}\text { \% Nema- Nematode } \\
\text { todes }\end{array}$ & $\begin{array}{c}\% \text { in } \\
\text { DWT }(\mu \mathrm{g})\end{array}$ & $0-1 \mathrm{~cm}$ \\
\hline C0 & 175 & 1802 & 80.4 & 0.130 & 30.3 \\
C14 & 733 & 1089 & 88.5 & 0.060 & 44.8 \\
C36 & 1522 & 262 & 83.0 & 0.077 & 38.7 \\
C41 & 2200 & 1275 & 92.2 & 0.063 & 31.2 \\
C59 & 4909 & 960 & 95.6 & 0.065 & 38.4 \\
CG & 3800 & 673 & 89.5 & 0.040 & 52.7 \\
C125 & 4951 & 475 & 93.0 & 0.046 & 53.2 \\
C25 & 2270 & 785 & 93.6 & 0.059 & 41.0 \\
PE12can & 344 & 1366 & 91.4 & 0.205 & 38.6 \\
PE13par & 137 & 705 & 89.3 & 0.196 & 47.0 \\
PE14can & 3097 & 1443 & 98.0 & 0.125 & 60.4 \\
PE15par & 397 & 1571 & 93.5 & 0.105 & 42.1 \\
PE17can & 4323 & 617 & 95.1 & 0.063 & 65.1 \\
G0 & 153 & 1707 & 85.3 & 0.084 & 26.7 \\
G100 & 764 & 333 & 85.4 & 0.073 & 14.2 \\
G30 & 2625 & 887 & 93.5 & 0.038 & 35.0 \\
G56 & 2373 & 555 & 91.6 & 0.038 & 46.0 \\
G85 & 1794 & 512 & 94.4 & 0.040 & 53.1 \\
& & & & & \\
\hline
\end{tabular}

density of 1.13 and a wet weight-dry weight conversion factor of 0.5 .

Additional morphometric information came from 3 other studies in which we were involved: the Goban Spur (NE Atlantic; Soetaert et al. 1997, Vanaverbeke et al. 1997), the Ligurian Sea (NW Mediterranean; Soetaert et al. 1995) and the Kenyan margin (Indian ocean; A. Muthumbi et al. unpubl.). Sampling procedures and analyses in these studies were similar to the current study.

\section{RESULTS}

\section{Nematode vertical and horizontal distribution patterns}

The trends in total meiofauna density and biomass were described in Flach et al. (2002); only the main points will be repeated here. Meiofauna density, relative contribution of nematodes, and mean nematode weight and fraction in the upper $\mathrm{cm}$ are shown in Table 2. Generally, metazoan meiofauna density and biomass were higher on the La Coruña transect (Flach et al. 2002). The relative contribution of nematodes to total meiofauna density was in the range of 80 to $98 \%$ and generally increased with increasing water depth (Table 2).

On average $42 \%$ of the nematodes were present in the upper $1 \mathrm{~cm}$ of the sediment. The concentration near the surface was highest in the deep canyon station (65\%), lowest in 1 station located on the seamount (14\%), in which the irregularities in the porosity profile indicated strong (perhaps physical) disturbance (Table 2).

\section{Nematode morphology}

Of the 144 sediment slices that were examined, only in 29 cases were fewer than 30 nematodes measured, mainly from the deeper parts of the sediment of abyssal plain stations. On average, some 70 individuals per sediment slice were measured. The final database consisted of 10134 length and width measurements, which also recorded the stage and, for adults, the gender of each individual nematode from the 18 localities along the Iberian ocean margin.

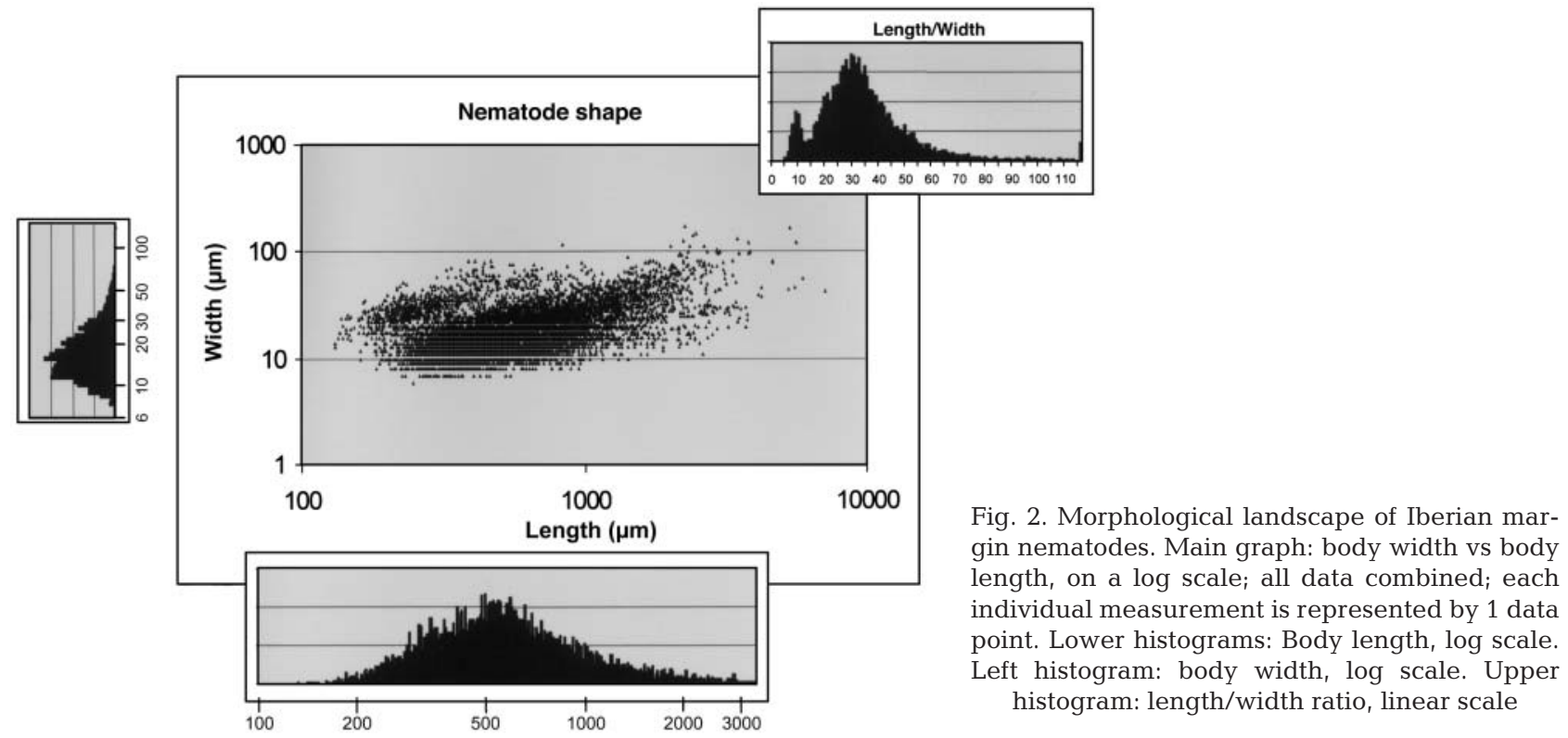




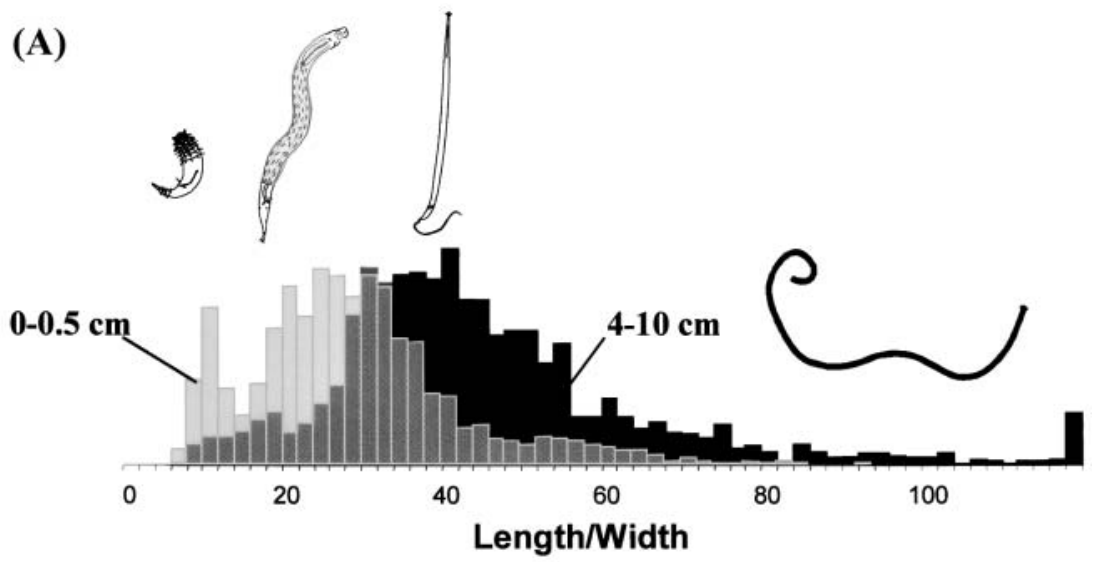

(B) Station $\mathrm{C0}, \mathbf{1 7 5 \mathrm { m }}$
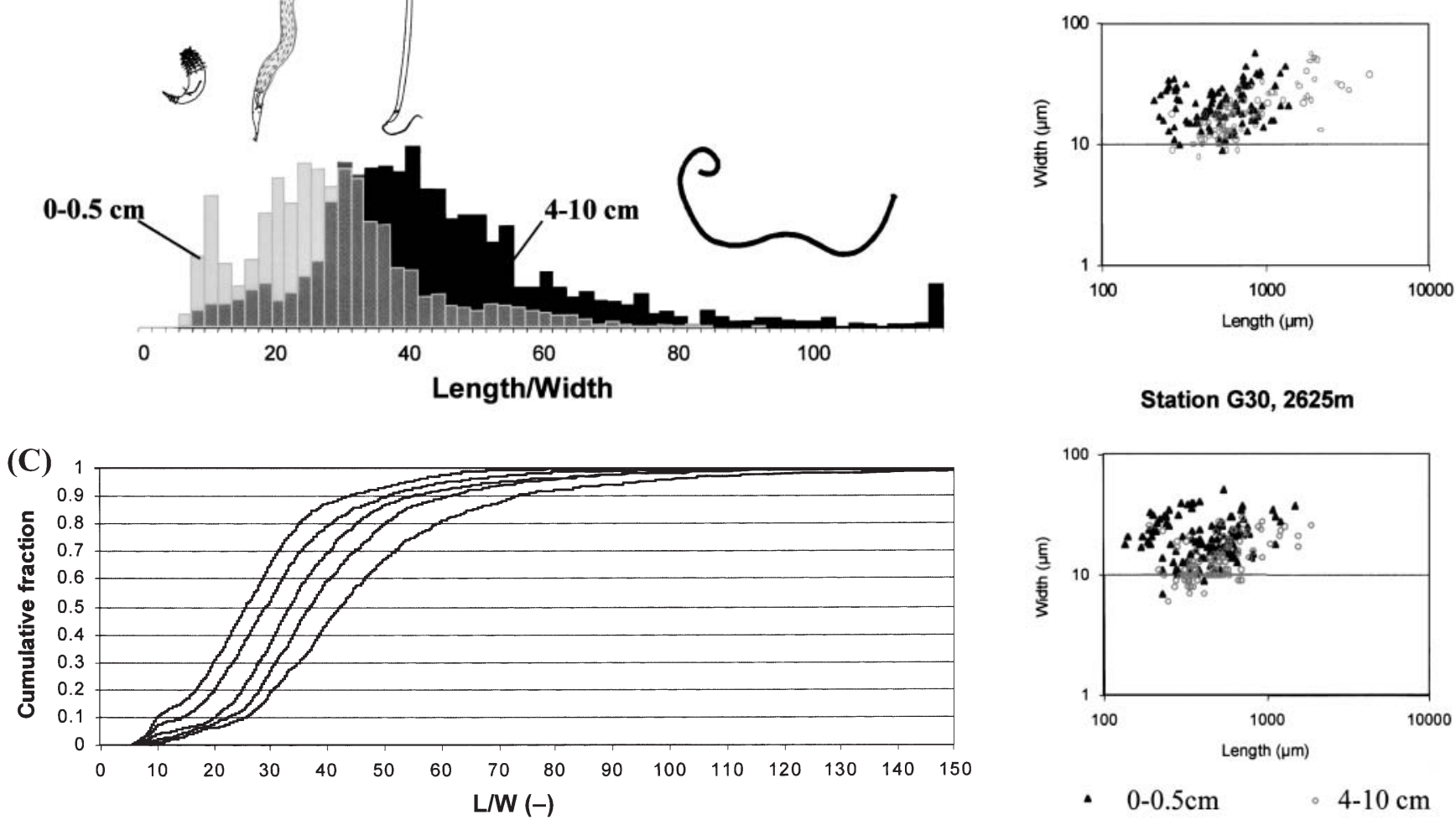

Station G30, 2625m

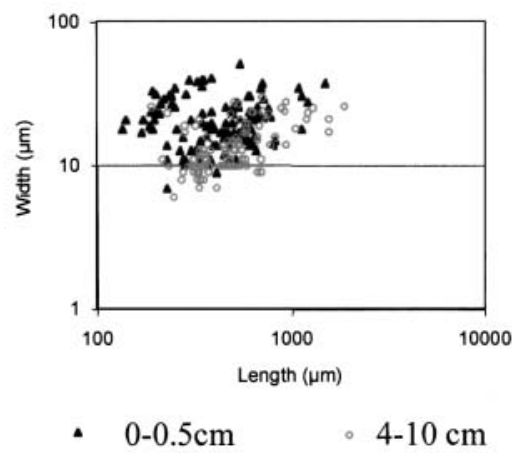

Fig. 3. Change of nematode morphology with depth into the sediment. (A) Histogram of length/width ratios for the upper $0.5 \mathrm{~cm}$ of the sediment (light grey bars in front), and the lower 4 to $10 \mathrm{~cm}$ (dark grey, background); data from all sampling stations combined. (B) Morphological landscape (body width vs length [L/W] for the upper $0.5 \mathrm{~cm}$ and the lower, 4 to $10 \mathrm{~cm}$, sediment layer, for 2 stations, 1 on the shelf (C0) and 1 on the lower slope (G30). (C) Cumulative distribution of the L/W ratios for every second layer of the sediment from left to right: 0 to $0.5 \mathrm{~cm}, 1$ to $1.5 \mathrm{~cm}, 2$ to $3 \mathrm{~cm}, 4$ to $5 \mathrm{~cm}, 5$ to $10 \mathrm{~cm}$; data from all sampling stations combined. -: dimensionless

Fig. 2 gives the ensemble of all measurements in a width/length plot and the frequency distribution of the body length, body width and length to width (L/W ratio). The latter is a quantitative measure of the shape of nematodes, with slender animals having high L/W ratios, plump ones having low $\mathrm{L} / \mathrm{W}$ ratios. The size and shape of nematodes shows a remarkable diversity, spanning more than 1 , almost 2 orders of magnitude. The longest nematode was found at $2200 \mathrm{~m}$ and was more than $7 \mathrm{~mm}$ long; the shortest adult, found at $397 \mathrm{~m}$, measured only $130 \mu \mathrm{m}$; the median nematode length was $531 \mu \mathrm{m}$, the average length $660 \mu \mathrm{m}$. Nematode body width varied between 6 and $>150 \mu \mathrm{m}$, the median being $18 \mu \mathrm{m}$, the average width $21 \mu \mathrm{m}$. The most slender nematode $(2.6 \mathrm{~mm}$ long and only $11 \mu \mathrm{m}$ thick) was a juvenile observed in the deepest sediment layer of a station at $3800 \mathrm{~m}$. The stoutest nematode (220 $\mu \mathrm{m}$ long, $52 \mu \mathrm{m}$ wide), a female, was found at $2200 \mathrm{~m}$ depth. It should be noted that due to the limited area sampled, we may have missed the rarer large animals, and some of the smallest organisms may have passed through the $32 \mu \mathrm{m}$ mesh; thus, nematodes with more extreme measurements may well exist. In addition, for the upper sediment slices, not all nematodes may have been measured, so there is a slight overestimate of the nematodes from the deeper layers.

In the length versus width graph there are 2 distinct morphological groups, forming clearly demarcated oval regions (Fig. 2). The uppermost region consists of relatively plump nematodes, generally less than $500 \mu \mathrm{m}$ long and more than $12 \mu \mathrm{m}$ wide. More than $90 \%$ of all measured nematodes belong to the other morphotype, which is significantly more slender and on average much longer than the former. In the length/width histogram, these 2 morphotypes are visualized as 2 peaks, at L/W ratios of 8 and 30 respectively, with a distinct minimum at a ratio between 12 to 15. In what follows, we will determine the distinction between both groups at a L/W ratio of 14 .

In Fig. 3 we have depicted how the nematode morphological landscape deforms in response to depth in the sediment. It is clear that nematode shape is distinctly different in the upper part of the sediment compared to the deeper part. The cumulative plots of $\mathrm{L} / \mathrm{W}$ 
(A)

$$
\text { Length/Width }
$$
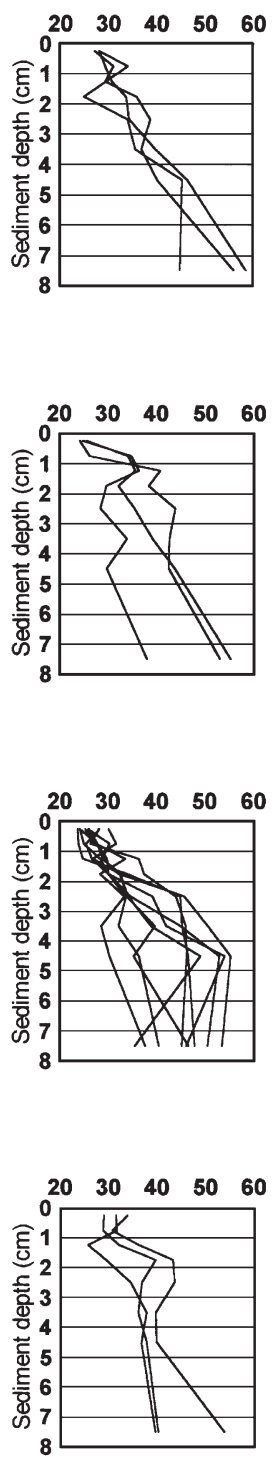

(B)

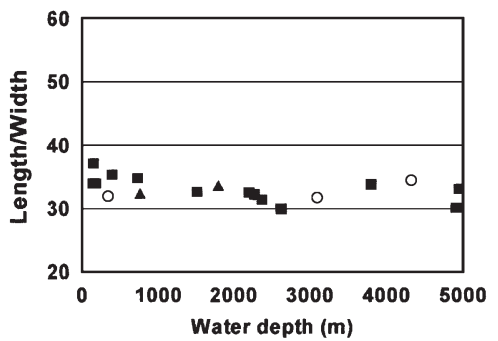

○ Canyon
Length $(\mu \mathrm{m})$
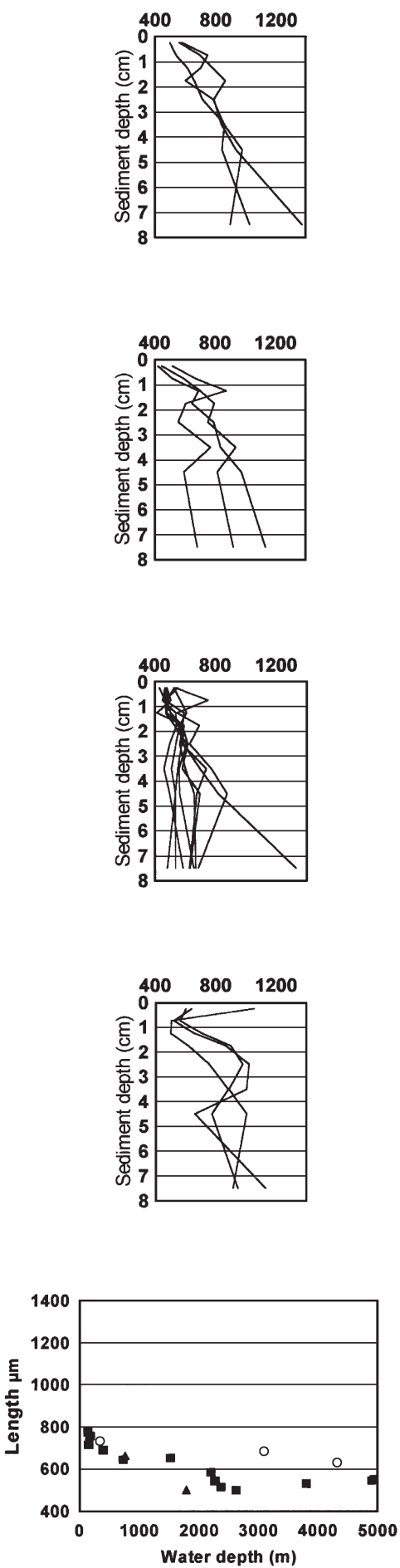

- Sea mount
Width $(\mu \mathrm{m})$
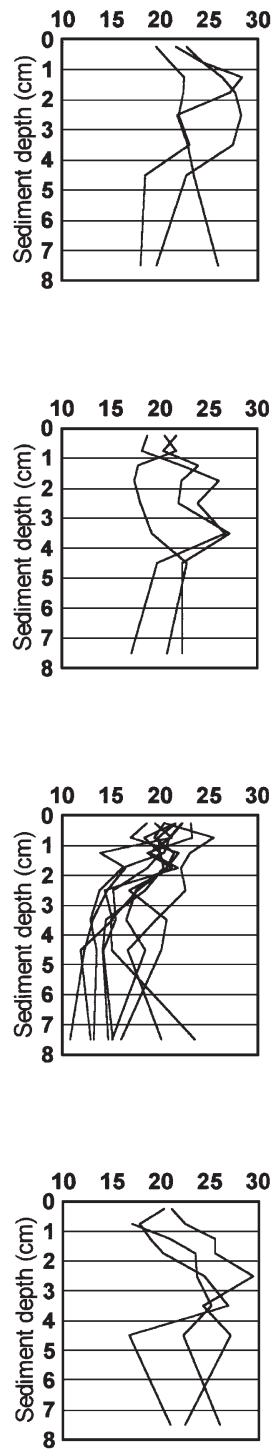

Fig. 4. (A) Mean nematode length/width ratio (left), body length (middle), and body width (right) vs sediment depth for each sampling station. Stations are divided into shelf (100 to $200 \mathrm{~m})$, upper slope (400 to $1000 \mathrm{~m})$, lower slope and abyssal plain (1500 to $5000 \mathrm{~m}$ ) and canyon. (B) Mean nematode length/width ratio (left), body length (middle) and body width (right), averaged over the sediment, as a function of water depth. Note that the same scale is used as in (A) 
(Fig. 3C) are progressively displaced towards higher L/W ratios with increasing depth into the sediment, demonstrating that nematode shape shifts from plumper forms near the sediment surface to significantly more slender nematodes at depth. In the upper $0.5 \mathrm{~cm}$, about $15 \%$ of the nematode community consists of the plump type; $50 \%$ of the nematodes have a L/W ratio $<25$ (Fig. 3A,C). At 1 to $1.5 \mathrm{~cm}$ depth, the contribution of plump nematodes decreased to about $10 \%$; the median L/W ratio was 29 (Fig. 3C). Below $4 \mathrm{~cm}$ depth, only $3.5 \%$ belong to the corpulent type; median L/W ratio was 39 (Fig. 3A,C). The disappearance of the plump nematodes with increasing sediment depth and the appearance of significantly more slender nematodes are equally responsible for the shifting overall morphology (Fig. 3A-C).

An ANCOVA showed a highly significant effect $(\mathrm{p}=$ 0.00 ) of sediment depth both on the log-transformed body width $\left(F_{(1,10059)}=397\right)$ and length data $\left(F_{(1,10059)}=\right.$ $112)$. The slope of the regression was significantly different $(p=0.00)$ amongst the stations (interaction $F_{(17,10059)}=10.4,10.98$ for width and length respectively), indicating that the changes in the sediment were not consistently the same in all stations.

In Fig. 4 the average features of nematode morphology are displayed as they change in the sediment for each sampling station (Fig. 4A), and with water depth (Fig. 4B). Worth noting is that, despite clear trends, there is considerable variability in the data; this variability can be seen in Fig. 3B, in the data from a shelf and lower slope station.

We subdivided the stations into 4 different groups: the canyon, shelf, upper slope, and lower slope abyssal plain stations conform to the distinction in geochemical conditions reported in Epping et al. (2002) and van der Zee et al. (2001) (see also 'Discussion'). It is obvious that morphological changes are more pronounced when expressed as a function of sediment depth (Fig. 4A) than when plotted versus water depth (Fig. 4B). Mean L/W ratios vary from about 20 to 60 in the sediment; vertically averaged, this variation is narrowed to between 30 and 40. Mean nematode lengths may almost triple with sediment depth from 400 to $>1200 \mu \mathrm{m}$; vertically averaged lengths stay well below $800 \mu \mathrm{m}$. The mean nematode width varies between 10 and $30 \mu \mathrm{m}$ vertically in the sediment and between 16 and $26 \mu \mathrm{m}$ with water depth.

For each of the stations investigated, the nematode L/W ratios consistently increase with depth in the sediment. At shelf and upper slope, the trend continues till the deepest layer, whereas on the upper slope and abyssal plain stations, the increase in L/W ratios levels off at smaller sediment depth. On the shelf and, to a lesser extent, on the upper slope and canyon stations, the changes in $\mathrm{L} / \mathrm{W}$ ratios are due to increases in body length, whereas the body width does not display a consistent pattern with depth into the sediment. In contrast, at the lower slope and abyssal stations, the body length of the nematodes only marginally increases deeper into the sediment, but body width shows a pronounced reduction. One clear exception was Stn C41, at $2200 \mathrm{~m}$ at the La Coruña transect, where mean length at 5 to $10 \mathrm{~cm}$ was well over $1000 \mu \mathrm{m}$, but this estimate was based on 14 measurements only.

\section{DISCUSSION}

\section{Abiotic characteristics of the stations}

The abiotic conditions of the overlying water have been listed in van der Zee et al. (2001) and the sediment composition by Flach et al. (2002). At depths shallower than $1500 \mathrm{~m}$, the temperature of the overlying water is between 10 and $13^{\circ} \mathrm{C}$, and drops rapidly to less than $4^{\circ} \mathrm{C}$ below that depth. The oxygen concentration of the overlying water decreases rapidly from about 210 to $240 \mu \mathrm{mol} \mathrm{O} \mathrm{I}^{-1}$ at depths $<150 \mathrm{~m}$ to less than $200 \mu \mathrm{mol}$ $\mathrm{O}_{2} \mathrm{l}^{-1}$ at 200 to $1500 \mathrm{~m}$, below which it restores rapidly to about $250 \mu \mathrm{mol} \mathrm{O} \mathrm{O}_{2} \mathrm{l}^{-1}$. With the exception of the silty sediments in the canyon site on the shelf, sediments are sandy at depths shallower than $1500 \mathrm{~m}$ and finegrained at greater depths. Porosities increase more or less regularly with bathymetric depth, from a volumetric water content of $55 \%$ on the shelf to above $75 \%$ in the deepest sites (Flach et al. 2002).

The organic carbon respiration rates of the sediment were estimated by modeling nutrient-depth and oxygen profiles, the former measured on extracted porewater, the latter with Clark-type micro-electrodes mounted on a benthic profiling lander by Epping et al. (2002). Except for the canyon sites, there is a gradual, exponential decrease from about $15 \mathrm{~g} \mathrm{C} \mathrm{m}^{-2} \mathrm{yr}^{-1}$ on the shelf to about $1 \mathrm{~g} \mathrm{C} \mathrm{m}^{-2} \mathrm{yr}^{-1}$ at $5000 \mathrm{~m}$ depth. This decrease in organic matter respiration rates is not reflected in the concentrations of organic carbon in the upper part of the sediment, which varies between 0.2 to $0.8 \%$. The canyon receives considerably larger amounts of organic matter, well over $20 \mathrm{~g} \mathrm{C} \mathrm{m}^{-2} \mathrm{yr}^{-1}$ on the shelf, around $10 \mathrm{~g} \mathrm{C} \mathrm{m}^{-2} \mathrm{yr}^{-1}$ at $3000 \mathrm{~m}$ depth, and $3.5 \mathrm{~g} \mathrm{C} \mathrm{m}^{-2} \mathrm{yr}^{-1}$ at $4200 \mathrm{~m}$. Because of the refractory nature of this organic matter, the total organic carbon content in the canyon sediments is higher than $2.5 \%$ (Epping et al. 2002).

The gradients in organic matter flux are reflected in the biogeochemical conditions of the sediment. There is a build-up of reduced substances (e.g. ammonium, reduced iron and manganese compounds) at depths in the sediment of the stations shallower than $2000 \mathrm{~m}$ and in the canyon (van der Zee et al. 2001, Epping et al. 


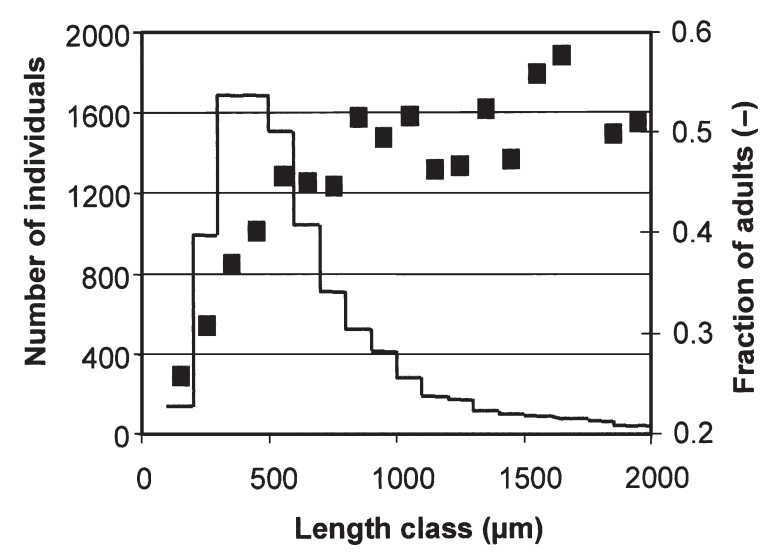

Fig. 5. Histogram of nematode body length frequencies, on a linear scale, and the relative contribution of adults in each length class ( $\square$ ). All data combined

2002). Except for the canyon, some 50 to $100 \%$ of all organic matter is respired aerobically, and this fraction generally increases from the shelf to the deep sea. In the canyon, the share of oxygen as an electron acceptor is much less, about $30 \%$ at depths below $3200 \mathrm{~m}$, and $70 \%$ at the deepest site. Oxygen penetrates less than $1 \mathrm{~cm}$ into the sediment on the shelf, whereas at depths greater than $2000 \mathrm{~m}$, oxygen more steadily declines until exhaustion at around 4 to $5 \mathrm{~cm}$ depth in the sediment (Epping et al. 2002). Oxygen penetration depth is reduced in the canyon, around 1 and $3 \mathrm{~cm}$ at 3097 and $4280 \mathrm{~m}$ respectively. Similarly, the manganese redox boundary, as modeled by van der Zee et al. (2001), is shallow ( $<1 \mathrm{~cm}$ deep) on the shelf and deeper than $5 \mathrm{~cm}$ at water depths $>2000 \mathrm{~m}$, except for the canyon site at $3100 \mathrm{~m}(1.3 \mathrm{~cm})$.

\section{Nematode patterns}

Nematode length and width are robust parameters that are easily measured using non-destructive methods. This makes nematodes particularly suited for analyzing body size distributions. Although a simple measure of length and width cannot do justice to the wide morphological variation that exists in the nematode taxon, we have shown that they form a unique, somewhat under-explored probe for evaluating the impact of the environment on their communities.

There are several aspects of our analysis that merit closer attention: (1) the versatility of nematode shape along the ocean margin and the existence of 2 morphotypes; (2) the marked changes in shape with depth into the sediment; and (3) the effect of this vertical variation on bathymetric trends and the size-depth hypothesis.

\section{Description of the nematode morphology along the ocean margin}

Body length distributions of ocean margin nematodes were discussed in detail in a number of papers (Soetaert \& Heip 1989, Vanhove et al. 1995, Vanreusel et al. 1995a, Soltwedel et al. 1996, Sommer \& Pfannkuche 2000). Typically, lengths are log-normally distributed, with the distributions skewed towards the smaller sizes and a long tail extending in the longer size classes. Our analysis confirms this general shape (Fig. 2, lower histogram, log scale). Attempts to explain this skewed distribution have not yet been made, so we will try to give a qualitative explanation. Individuals will grow through successive length stages until they either die or become adults. In the latter case, most of the energy in excess of maintenance is channeled into reproductive rather than somatic growth. In Fig. 5, we have depicted the length-frequency diagram (on a linear scale) and the relative proportion of adults in each size group. The skew can at least partly be explained by individuals reaching adulthood in a certain class, which slows their growth, or prevents them from growing into the next size class. In the smallest size fractions, most of the individuals are juveniles, so that the probability of growing into the next size class is relatively high. With increasing length, the relative contribution of adults becomes larger and stabilizes at about $50 \%$ at body lengths of $800 \mu \mathrm{m}$, the probability of entering the next class is reduced. The fact that the peak density (around $400 \mu \mathrm{m}$ ) is reached before the contribution of adults to the population stabilizes, is most likely due to mortality.

When plotting the morphometric data in a lengthwidth graph (Fig. 2), the versatility of nematode shape along the margin becomes apparent. In 1 sediment core one may find nematodes that vary by 1 , almost 2 , orders of magnitude in length and width. Some are very long and thin; others are very short and corpulent.

To assess whether the morphological landscape observed along the Iberian margin is a typical feature of ocean margin nematode communities, we have plotted similar data from 3 other margin areas (Fig. 6). They are the Ligurian Sea (NW Mediterranean: $>4200$ nematodes; 6 stations from 160 to 1220 m depth; Soetaert et al. 1997), the Goban Spur (NE Atlantic: >3000 nematodes; 7 stations 208 to 2760 m; Vanaverbeke et al. 1997), and the Kenyan margin (Indian Ocean: 600 Nematodes; 3 stations, 500 to 2000 m; A. Muthumbi unpubl.). The nematode morphology in these disparate regions is very similar to that of the Iberian margin (Fig. 2) with respect to total range and variability.

In addition, the existence of 2 morphotypes, 1 relatively long and slender, and 1 short and stout, is con- 


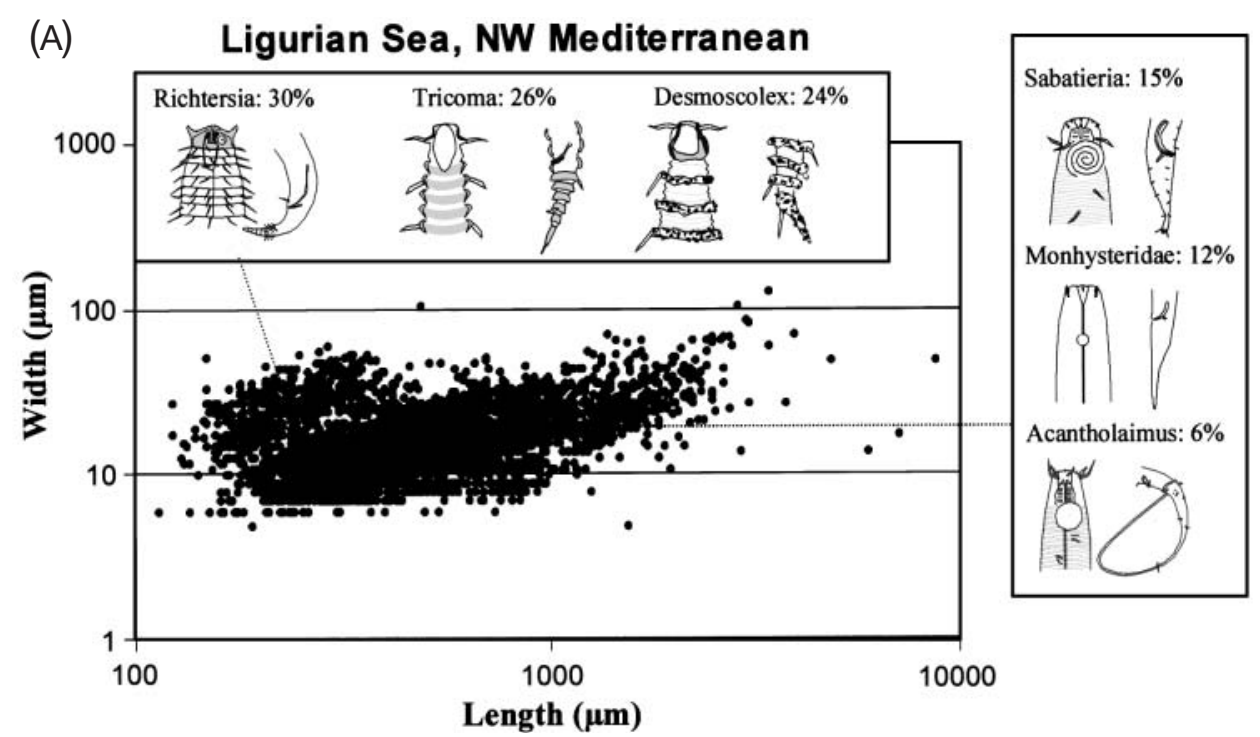

(B)

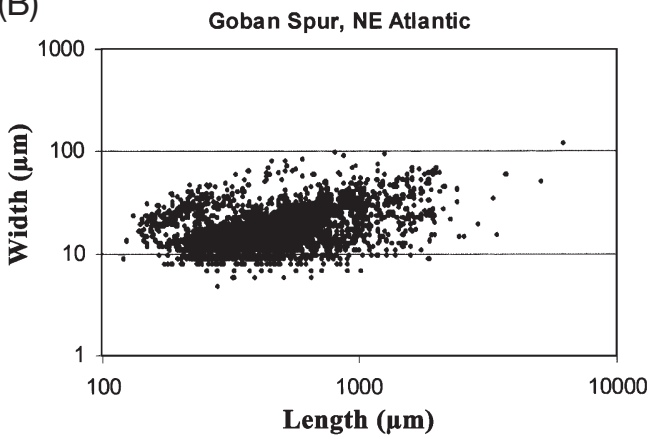

(C)

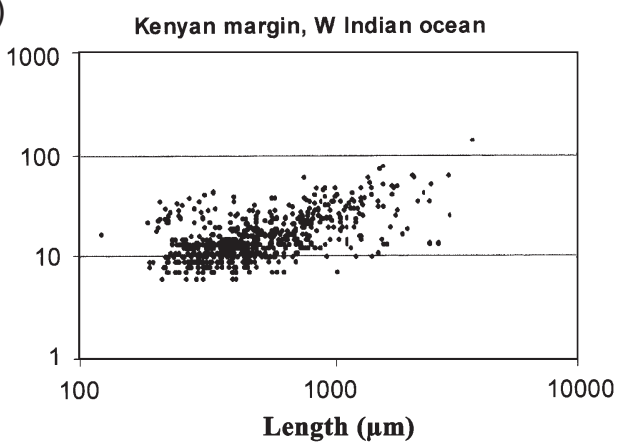

Fig. 6. Morphological landscape of margin nematodes from (A) the Ligurian Sea (Soetaert et al. 1995), (B) the Goban Spur (Vanaverbeke et al. 1997) and (C) the Kenyan margin (A. Muthumbi unpubl.). For the Ligurian Sea samples, the 3 main genera of both morphotypes are depicted

firmed from these data. Clearly, notwithstanding the large geographical separation between these 4 margin areas (Figs. $2 \& 6$ ), nematode shape is constrained to these 2 morphotypes with extreme robustness. There are arguments that such persistent features can only occur if there is some kind of morphological canalization via conflicting constraints (Kauffman 1993), so to explain our data, we must search for constraints that would either select for the slender or for the corpulent shape.

Before trying to elucidate the pros and cons of both morphological groups, we need to assess whether, in either of these morphotypes, the similarities in shape are due to common descent (phylogenetic association) or due to convergence. The distinction is important, as the presence of convergence, where the same shape is present in distantly related taxa, is strong evidence for selective adaptation, where the similarities are manifestations of comparable evolutionary processes. Con- versely, when all members in 1 group are closely related, the morphological constraints could have been imposed by the phylogenetic lineage (Brooks \& McLennan 1993, Cadle \& Greene 1993). We do not have taxonomic information for the Iberian margin nematodes, but in the samples from the Ligurian Sea (Fig. 6), each L/W measurement has a species name associated with it (Soetaert et al. 1995), so we will use this data set instead. The 3 most abundant nematode genera from both types of mophologies on the Ligurian margin are given in Fig. 6, which demonstrates that to a certain degree, the 2 morphotypes indeed impart taxonomic similarity. The slender type of nematodes comprises most species belonging to the more 'classical' nematode orders Chromadorida, Monhysterida and Enoplida. In contrast, members of the order Desmoscolecida (Decraemer 1985) group nearly exclusively in the plump morphotype cluster. Together they comprise about $55 \%$ of all specimens there, of which 


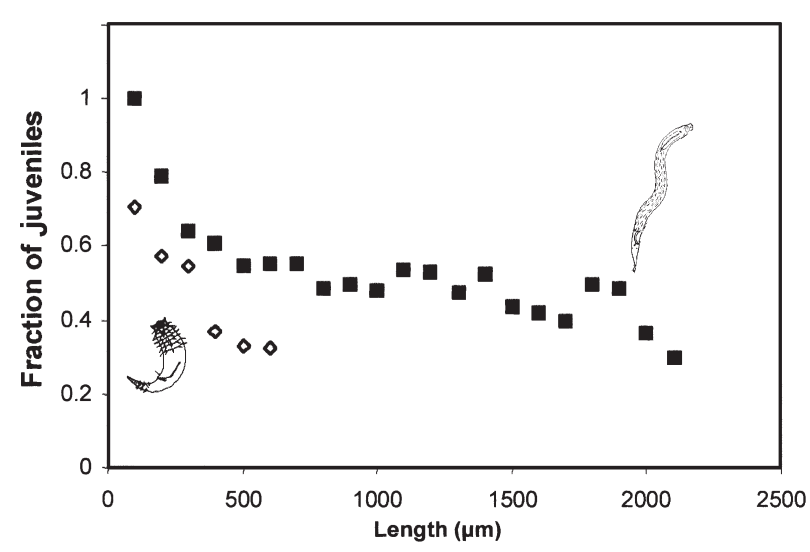

Fig. 7. Proportion of juveniles in a length class for the plump $(\diamond)$ and for the slender $(\bullet)$ morphotype. All data combined

the genera Tricoma (Soetaert \& Decraemer 1989) and Desmoscolex (Soetaert 1989) are most abundant. Interestingly, these nematodes are joined by three species belonging to the genus Richtersia (30\%), a Chromadorid, belonging to the family of the Desmodoridae (Soetaert \& Vincx 1987). The remaining $15 \%$ of the specimens then belong to other, less numerous genera.

The fact that the short, corpulent shape is not the exclusive niche of 1 phylogenetic lineage is compelling enough to search for a reason for its existence. After all, it is quite aberrant, compared to the worm-like features of most nematodes. It is instructive to note that both the desmoscolecids and the Richtersia species share the presence of cuticular protrusions, which might be viewed as a protective covering. In the desmoscolecids they consist of so-called desmen, ring-like expansions that are often reinforced with sediment grains (Decraemer 1985, see Fig. 6). The plump members of the genus Richtersia in the Mediterranean are characterised by the occurrence of many long, relatively rigid setae, protruding backwards. Moreover, some long and slender members of both groups were much less 'armored'. In 3 aberrant new members of the desmoscolecid genus Protricoma, the long body is finely annulated (Decraemer \& Soetaert 1989); in 2 more slender species of the genus Richtersia, the setae are much shorter (Soetaert \& Vincx 1987). These observations suggest that armor and corpulence often come in pairs. There does not seem to be a similarity in feeding habit between both groups. The desmoscolecids, with their minute buccal cavity and glandular pharynx, can only feed on very small (bacterial-sized) prey, whereas Richtersia, equipped with a large mouth and a muscular pharynx, probably feeds on much larger food items.

Although the length of both morphotypes overlaps in the shortest length classes $(<600 \mu \mathrm{m})$, inspection of the stage distribution (juveniles vs adults) in both morphotypes (Fig. 7) shows a distinct difference. Adults are poorly represented in the smallest length classes of the slender type $(0 \%$ in the 100 to $200 \mu \mathrm{m}$, increasing to $45 \%$ in the 500 to $600 \mu \mathrm{m}$ length class), but they have a much bigger share in the plump type group $(27 \%$ in the 100 to $200 \mu \mathrm{m}, 65 \%$ in the 500 to $600 \mu \mathrm{m}$ length class). In comparison, such high dominance (>65\%) of adults is only achieved beyond the $1500 \mu \mathrm{m}$ length class in the slender type of nematodes. Therefore, it is likely that the shorter length classes are mainly growthrough stages for the slender type, whereas this is less the case for the corpulent type. This then suggests that there is a larger reduction of fitness induced by the small size for the slender type of nematodes than for the plump ones.

The fitness of a population is a function of physiological as well as ecological features, some of which clearly depend on organism size, such as metabolic rates, the tolerance to chemical stress, the ability to move or migrate and vulnerability to predation.

Smaller-sized species generally have higher growth rates (biomass increase, Peters 1983). Although it is not known whether this also applies to deep-sea nematodes, small organisms do also have the additional advantage of reduced age at first breeding. Juveniles, by definition, do not reproduce, and the intrinsic growth rate of a population (density increase) is particularly sensitive to early reproduction (McCallum 2000). As such, communities composed of small individuals generally have higher intrinsic rates of increase. If in our samples, the age at maturity indeed depends on the size of the adult, we would expect those nematode communities that are, on average, composed of larger species to be more dominated by juveniles. We tested this for the Iberian margin samples, where we defined 'communities' as the ensemble of nematodes in any 1 layer of the sediment, excluding those layers where total number of individuals was less than 50. Unexpectedly, when regressing the proportion of juveniles against mean adult dry weight, the relationship was not significant (not shown); however, there was a highly significant and positive relationship between the proportion of juveniles and mean adult length ( $p<0.001 ;$ Fig. 8). The biological significance of this subtle distinction is unclear. Perhaps an increase in length requires more energy compared to comparable increases in body width. It could be that the former requires structural growth (e.g. protein synthesis, which is energy-consuming), whereas body width mainly increases due to allocation of reserve substances, which requires less energy.

Mobility is 1 factor that would promote larger size, as it may provide accessibility to other food sources. As will be apparent below, the longer and more mobile 
nematodes penetrate much deeper into the sediment than their plump and presumably rather immobile relatives (see also Soetaert \& Heip 1989). As long nematodes often have longer guts, the increase in length could also affect the food transit time in the gut and therefore increase its absorption efficiency. In addition, the vulnerability of individuals to predator attack is often inversely related to the size of the animals (Peters 1983). For nematodes, it may be more increased body width rather than length that could reduce predatory mortality, as the attack may be head-first or tail-first and a predator must have a larger mouth cavity to swallow a fat compared to a thin nematode. Even if predators try to swallow nematodes from the side, thick nematodes may not break as easily as very thin ones. This, combined with the presence of protective protrusions in most of the corpulent species, strongly suggests that defense against predation might be an important factor giving selective advantage to this morphotype.

Increased body width also decreases the capacity for the uptake of oxygen; the thinner the body, the less the oxygen diffusion limitation and the higher the tolerance towards low oxygen levels (see 'Vertical gradients'). The fact that the thick desmoscolecids are most often observed in oligotrophic muds as well as in coarse, well-aerated sands, indeed indicates that oxygen availability affects their abundance. Finally, as a general rule, larger (or thicker) animals often allocate a larger amount of their food to storage products rather than to structural growth. This may provide a buffer against environmental variability (Kooijman 1986), as the amount of time that they can remain food-starved increases with the amount of reserve substances. Whether this is significant in deep-sea environments which do not exhibit extreme variability in organic matter deposition, is unclear.

It is impossible to designate one of these factors to be the most important structuring component leading to the observed bimodality. The significant, positive regression of the proportion of juveniles within a nematode community versus mean adult body length, and not versus mean body weight, suggests that thick and thin nematodes of similar lengths have comparable rates of increase. If true, the corpulent nematodes, due to their small length, may have the advantage of a high intrinsic rate of increase, and due to their greater width and the presence of armor they may have a better defense against predation than similar-sized nematodes that are much thinner. In addition, their bodies may store larger amounts of reserve products. The price to be paid for such obesity is reduced mobility, which effectively reduces the living space of these organisms to the upper layers of the sediment (see next subsection).

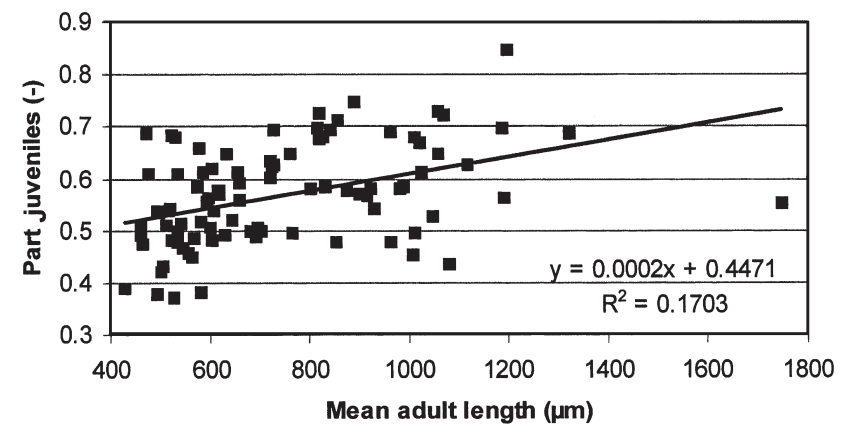

Fig. 8. Proportion of juveniles as a function of mean adult size within a community. For our definition of 'community', see text

\section{Vertical gradients}

Nematode vertical distribution (Table 2) shows that, on the shelf, more than $50 \%$ of nematodes are present in the anoxic zone of the sediment (Epping et al. 2002), below the manganese redox boundary (van der Zee et al. 2001). On the abyssal plain nearly all nematodes reside in the oxic part.

It is clear from this and from the study in the NW Mediterranean (Soetaert \& Heip 1989) that depth in the sediment affects nematode shape much more profoundly than water depth. Notwithstanding the differences in spatial scale, all the indices, i.e. mean body length, body width or their ratio, exhibit much wider variability vertically (cm scale) compared to bathymetrically ( $\mathrm{km}$ scale). This finding is consistent with results from the 2 studies documenting that sediment depth has a larger impact on nematode species (Soetaert et al. 1995) or genus (Vanaverbeke et al. 1997) composition than water depth.

Shifts in nematode shape corresponding to sediment is not the same all over the bathymetric range. Nematodes tend to become longer with sediment depth on the shelf and on the upper slope, whereas they become distinctly thinner with depth in the sediment on the lower slope and abyssal plain. The canyon stations did not exhibit such clear trends, but were rather disturbed. This differential adaptation in shallow and deep stations can best be understood when considering the redox conditions of the sediment. Sediments are oxic until about $5 \mathrm{~cm}$ at deep stations (Epping et al. 2002). As the oxygen concentration gradually decreases with distance below the sediment surface, nematodes on average become thinner. This could be an adaptation to maximize the oxygen absorption efficiency per unit of volume (Jensen 1986, 1987), in a similar way as the higher affinity for uptake of nutrients observed in small phytoplankton compared to larger cells (Banse 1976). In completely anoxic parts of the 
sediment, such as on the shelf, reduced body width would increase the loss of oxygen to the environment instead, so this may not be an effective adaptation under these circumstances. Nematodes are rather tolerant of anoxia, but they do not survive long-term exposure (Moodley et al. 1997). Nevertheless, a substantial fraction (50 to $70 \%$ ) of the nematode community is observed below the oxic zone on the shelf, such that the oxic/anoxic interface cannot be considered a chemical barrier. As nematodes respire aerobically, they cannot be permanent residents there and, to avoid damaging conditions associated with long-term exposure to anoxia, they need the capacity to move away. It is possible that the trend of increased length reflects such increased mobility. The short nematodes may not be mobile enough, and these individuals are indeed not commonly observed at depth in the sediment (see Fig. 3). Similar shifts towards larger specimens at greater depth in the sediment were observed in the Mediterranean upper slope sediments by Soetaert \& Heip (1989), and in the sulfide-rich part of shallow sediments by Jensen (1987) and Wetzel et al. (1985). Jensen (1986) and Vanreusel et al. (1997) found that longer nematodes dominate in cold seep and hydrothermal sediments, compared to oxic neighboring sites. In addition to increased mobility, the association of nematodes with the oxic halo surrounding ventilated macrofaunal burrows is another factor that may allow their penetration below the redox front (Wetzel et al. 1985). Essentially, macrofaunal burrows fold back the oxic layer deep into the sediment, thus creating small-scale aerobic islands in a seemingly anoxic environment. The oxic zone surrounding these burrows is often very narrow and may be inhabited by very long and slender nematodes that use their body to bridge the gap between oxic and anoxic microniches (Wetzel et al. 1985). Based on the data set available, it is not possible to estimate the significance of this phenomenon, but one may note the presence of very long and thin organisms at greater depth in the sediment, whereas this particular shape is not observed in the upper layers (e.g. Fig. 3B).

Other environmental conditions that change drastically with sediment depth and that could qualify as determining factors impacting nematode size are food quality and quantity and porosity. However, it is unclear how food, which along the ocean margin decreases in quality, and quantity, both with sediment depth and water depth (Soetaert et al. 1996), would lead to increased length only vertically. Porosity in the Iberian margin sites decreases with distance to the sediment-water interface and increases slightly from the shelf to the abyssal plain. Increased compaction definitely can impact the nematode's ability to slide through the sediment, but how this would result in increased length on the shelf and in reduced width on the abyssal plain is not easily understood.

One other factor that is often quoted as impacting nematode sizes is grain size. Along the margin, sediment grain size changes notably with water depth, but not with depth in the sediment. As the opposite is true for nematode size, it is unlikely that this abiotic factor was important here.

With over $50 \%$ of the nematodes present in the anoxic part of the sediment, one might expect that this gives a competitive advantage over other metazoan meiofauna that generally do not penetrate as deep into the sediment (Flach et al. 2002). It has been suggested that chemosynthetic bacterial production may constitute an important food source for the benthic organisms that live in partly anoxic sediments (Soetaert et al. 2002). Due to bacterial anaerobic metabolism, chemical gradients of reduced compounds $\left(\mathrm{H}_{2} \mathrm{~S}, \mathrm{NH}_{3}\right)$ are established at greater sediment depths, and chemosynthetic microbial organisms can grow on the residual chemical energy contained in these substances. The low efficiency of energy recovery means that chemosynthetic production can only be a fraction of the original organic matter deposition. Nevertheless, as they require the simultaneous supply of reduced and oxidized compounds, the chemoautotrophic producers occur in very restricted zones of the sediment, where both these conditions are met. Such localized enrichments in bacterial standing stock might constitute a high-quality food source in an otherwise fooddiluted medium, which could give a competitive edge to those organisms that have access to this.

In order to test the potential importance of chemosynthetic bacterial production as a food source, we have made a rough calculation of its magnitude for a hypothetical shelf station at $150 \mathrm{~m}$ depth. Using the regressions against depth along the Iberian margin as derived by Epping et al. (2002), we arrive at a value of $0.24 \mathrm{molC}_{\text {org }} \mathrm{m}^{-2} \mathrm{yr}^{-1}$ organic matter anaerobically mineralized. Re-oxidizing the reduced substances that were formed upon anoxic mineralization of $1 \mathrm{molC}_{\text {org }}$ eventually requires $1 \mathrm{~mol} \mathrm{O}_{2}$ (Soetaert et al. 1996). Jorgensen et al. (1991) suggested that 7 to $9 \mathrm{~mol}$ of $\mathrm{H}_{2} \mathrm{~S}$ are required for mixed chemoautotrophic communities to assimilate $1 \mathrm{~mol}$ of $\mathrm{CO}_{2}$ under field conditions in anoxic water bodies. Taking into account the stoichiometry of sulfate reduction, this gives a potential net chemosynthetic production of $0.0625 \mathrm{molC}_{\text {org }}$ for each mole of organic carbon mineralized anaerobically. We add to that the chemosynthesis associated to nitrification (oxidation of ammonium to nitrate), where similar net growth efficiencies have been reported (Helder \& deVries 1983). A net bacterial chemosynthetic production of about $0.2 \mathrm{~g} \mathrm{C} \mathrm{m}^{-2} \mathrm{yr}^{-1}$ is obtained. To estimate nematode feeding requirements in the 
anoxic zone, we use allometric regressions relating nematode size and respiration, as in Soetaert et al. (1997) and assume a growth efficiency of 50\%. Respiration rates of $0.8 \mathrm{gC} \mathrm{m}^{-2} \mathrm{yr}^{-1}$ then give feeding requirements of $1.6 \mathrm{~g} \mathrm{C} \mathrm{m}^{-2} \mathrm{yr}^{-1}$, which is substantially higher than what is potentially supplied through chemosynthetic bacterial growth. We therefore conclude that, in addition to chemosythetic bacteria, these deep-dwelling nematodes must feed on detritus and/or on the heterotrophic bacteria growing on it.

\section{Horizontal gradients in nematode shape}

Organic matter mineralization rates along the Iberian ocean margin differ by more than 1 order of magnitude, from 1 to $16 \mathrm{~g} \mathrm{C} \mathrm{m}^{-2} \mathrm{yr}^{-1}$ (van der Zee et al. 2001, Epping et al. 2002). Nevertheless, there is a remarkable similarity of nematode body length and width in the upper $0.5 \mathrm{~cm}$ of the sediment all along the depth range. Only deeper into the sediment does nematode size change considerably (see Fig. 4A). Nematode body length and weight increase with sediment depth on the shelf and upper slope; the body width decreases with sediment depth on the lower slope and abyssal plain. In addition, the vertical distribution is slightly different in the first 2 as opposed to the second 2 areas, organisms penetrating deeper into the sediment on the shelf and upper slope (see Table 2). It is the combined effect of these 2 phenomena that cause the observed trend of decrease in size, when averaged over the entire sediment column, with increasing water depth.

Based on this study, it is clear that some trends that are ascribed to food availability can only be fully understood if the indirect effects of food, via the altered biogeochemical conditions, are considered as well. The intuitively appealing size-depth hypothesis that postulates that the 'dwarfism' in typical abyssal communities is an adaptation to low food availability is flawed by the observation that comparable degrees of 'dwarfism' occur in the surface of the much more eutrophic sediments on the shelf. We have demonstrated that the major structuring factor determining the size distribution of these ocean margin nematodes is the biogeochemical changes in the sediment that vary with depth. Under reduced conditions, selection for longer individuals occurs, which, when averaged over the entire sediment column, leads to nematode size becoming larger as the amount of food deposition increases. It is still true then that food is the main factor that impacts organism size, however, not directly as a limiting resource, but indirectly via the biogeochemistry. Perhaps we need to reconsider our use of the term 'dwarfism' to typify the nematode's small size in oligotrophic areas, and the description of the deep sea as a 'harsh' environment. Our data indeed suggest that the small nematode size in the deep sea is optimal, and deviations only occur when environmental conditions deteriorate, i.e. when sediments become less oxic.

This impact of the sediment biogeochemical conditions on the size (this work) and taxonomic structure (Soetaert et al. 1995, Vanaverbeke et al. 1997a) of nematodes might also explain why they respond differently to the deep-sea environment than many other organisms (Rex et al. 2001).

\section{CONCLUSION}

(1) The biogeochemical conditions of the sediment leave a strong imprint on the morphology of the most prominent members of the smaller-sized animals, the nematodes. We find consistent changes with sediment depth that can be understood as an adaptation to oxygen stress. When averaged over the entire sediment, these trends cause the well-documented miniaturization with reduced food deposition rates.

(2) Over evolutionary timescales, selection has led to 2 well-wrought nematode morphologies in ocean margin sediments. One shape is long and slender, which enables the nematode to move swiftly through the sediment, but which may make small, juvenile stages vulnerable to predation. The other type, short and corpulent, may have evolved towards reducing this predation pressure on the small individuals by a number of morphological adaptations, including a larger body width, and the development of armor. These adaptations undoubtedly bring about reduced mobility and a reduced capacity to withstand suboxic conditions, such that these nematodes are restricted to either the upper layer of the sediment, to the most oligotrophic deepsea sediments or to coarse sandy sediments.

Acknowledgements. This research was supported by the European Union (OMEX-II MAS3-CT96-0056). This is publication no. 2879 from the NIOO-CEMO. We thank 3 anonymous referees and Leon Moodley for useful suggestions concerning this manuscript.

\section{LITERATURE CITED}

Andrassy I (1956) The determination of volume and weight of nematodes. Acta Zool Hung 2:1-15

Banse K (1976) Rates of growth, respiration and photosynthesis of unicellular algae as related to cell size-a review. J Phycol 12:135-140

Brooks DR, McLennan DA (1993) Historical ecology: examining phylogenetic components of community evolution. In: Ricklefs RE, Schluter D (eds) Species diversity in ecological communities: historical and geographical perspectives. University of Chicago Press, Chicago, p 267-280 
Brown CJ, Lambshead PJD, Smith CR, Hawkins LE, Farley R (2001) Phytodetritus and the abundance and biomass of abyssal nematodes in the central, equatorial Pacific. DeepSea Res 48:555-565

Cadle JE, Greene HW (1993) Phylogenetic patterns, biogeography and the ecological structure of neotropical snake assemblages. In: Ricklefs RE, Schluter D (eds) Species diversity in ecological communities: historical and geographical perspectives. University of Chicago Press, Chicago, p 281-293

Calder WA (1984) Size, function, and life history. Harvard University Press, Cambridge

Carney RS, Haedrich RL, Rowe GT (1983) Zonation of fauna in the deep sea. In: Rowe GT (ed) The sea, Vol 8: Deep-sea biology. John Wiley \& Sons, New York, p 371-398

Danovaro R, Tselepides A, Otegui A, della Croce N (2000) Dynamics of meiofaunal assemblages on the continental shelf and deep-sea sediments of the Cretan Sea (NE Mediterranean): relationships with seasonal changes in food supply. Prog Oceanogr 46(2-4):367-400

Decraemer W (1985) Revision and phylogenetic systematics of the Desmoscolecidae (Nematoda). Hydrobiologia 120: 259-283

Decraemer W, Soetaert K (1989) Peculiar new deep-sea desmoscolecid species of the genus Protricoma (Nematode) from Corsica. Zool Sci 18(2):223-229

Epping EHG, van der Zee C, Soetaert K, Helder W (2002) On the mineralization and burial of organic carbon in sediments of the Iberian margin and Nazaré canyon (NE Atlantic). Prog Oceanogr 52:389-431

Flach E, Vanaverbeke J, Heip C (1999) The meiofauna:macrofauna ratio across the continental slope of the Goban Spur (north-east Atlantic). J Mar Biol Assoc UK 79:233-241

Flach E, Muthumbi A, Heip C (2002) Meiofauna and macrofauna community structure in relation to sediment composition at the Iberian margin compared to the Goban Spur (NE Atlantic). Prog Oceanogr 52:433-457

Gage JD, Tyler PA (1991) Deep-sea biology: a natural history of organisms at the deep-sea floor. Cambridge University Press, Cambridge

Galeron J, Sibuet M, Mahaut ML, Dinet A (2000) Variation in structure and biomass of the benthic communities at three contrasting sites in the tropical Northeast Atlantic. Mar Ecol Prog Ser 197:121-137

Heip C, Vincx M, Vranken G (1985) The ecology of marine nematodes. Oceanogr Mar Biol Annu Rev 23:399-489

Heip C, Duineveld G, Flach E, Graf G and 11 others (2001) The role of the benthic biota in sedimentary metabolism and sediment-water exchange processes in the Goban Spur area (N.E. Atlantic). Deep-Sea Res II 48 (14-15): 3223-3243

Helder W, de Vries RTP (1983) Estuarine nitrite maxima and nitrifying bacteria (Ems-Dollard estuary). Neth J Sea Res $17: 1-8$

Jensen P (1986) Nematode fauna in the sulphide-rich brine seep and adjacent bottoms of the East Flower Garden, NW Gulf of Mexico. IV. Ecological aspects. Mar Biol 92: 489-503

Jensen P (1987) Differences in microhabitat, abundance and body size between oxybiotic and thiobiotic free-living marine nematodes. Oecologia 71:564-567

Jorgensen BB, Fossing H, Wirsen CO, Jannasch HW (1991) Sulfide oxidation in the anoxic Black Sea chemocline. Deep-Sea Res 38:1083-1103

Kauffman SA (1993) The origins of order: self-organization and selection in evolution. Oxford University Press, Oxford
Kooijman SALM (1986) Energy budgets can explain body size relations. J Theor Biol 121:269-282

Lambshead PJD, Ferrero TJ, Wolff GA (1995) Comparison of the vertical distribution of nematodes from 2 contrasting abyysal istes in the northeast Atlantic subject to different seasonal inputs of phytodetritus. Int Rev Ges Hydrobiol 81:327-331

Lampitt RS, Antia AN (1997) Particle flux in deep seas: regional characteristics and temporal variability. DeepSea Res I 44:1377-1403

Levin LA, Huggett CL, Wishner KF (1991) Control of deep-sea benthic community structure by oxygen and organicmatter gradients in the eastern Pacific ocean. J Mar Res 49(4):763-800

Lohse L, Helder W, Epping EHG, Balzer W (1998) Recycling of organic matter along a shelf-slope transect across the NW European Continental Margin (Goban Spur). Prog Oceanogr 42:77-110

McCallum H (2000) Population parameters: estimation for ecological models. Blackwell Science, Oxford

Middelburg JJ, Soetaert K, Herman PMJ (1997) Empirical relationships for use in global diagenetic models. DeepSea Res 44:327-344

Moodley L, van der Zwaan GJ, Herman PMJ, Kempers L, van Breugel P (1997) Differential response of benthic meiofauna to anoxia with special reference to Foraminifera (Protista: Sarcodina). Mar Ecol Prog Ser 158:151-163

Moodley L, Chen GT, Heip C, Vincx M (2000) Vertical distribution of meiofauna in sediments from contrasting sites in the Adriatic Sea: clues to the role of abiotic versus biotic control. Ophelia 53(3):203-212

Peters RH (1983) The ecological implications of body size. Cambridge University Press, Cambridge

Pfannkuche O, Soltwedel T (1998) Small benthic size classes along the NW European continental margin: spatial and temporal variability in activity and biomass. Prog Oceanogr 42:(1-4)189-207

Relaxans JC, Deming J, Dinet A, Gaillard JF, Sibuet M (1996) Sedimentary organic matter and micro-meiobenthos with relation to trophic conditions in the tropical northeast Atlantic. Deep-Sea Res I 43:1343-1368

Rex MA, Etter RJ (1998) Bathymetric patterns of body size: implications for deep-sea biodiversity. Deep-Sea Res II 45: 103-127

Rex MA, Stuart CT, Etter RJ (2001) Do deep-sea nematodes show a positive latitudinal gradient of species diversity? The potential role of depth. Mar Ecol Prog Ser 210: 297-298

Rowe G, Sibuet M, Deming J, Khripounoff A, Tietjen J, Macko S, Theroux R (1991) 'Total' sediment biomass and preliminary estimates of organic carbon residence time in deep-sea benthos. Mar Ecol Prog Ser 79:99-114

Schwinghamer P (1983) Generating ecological hypotheses from biomass spectra using causal analysis: a benthic example. Mar Ecol Prog Ser 13:151-166

Sebens KP (1987) The ecology of indeterminate growth in animals. Annu Rev Ecol Syst 18:371-407

Sibuet M, Lambert CE, Chesselet R, Laubier L (1989) Density of major size groups of benthic fauna and trophic input in deep basins of the Atlantic Ocean. J Mar Res 47:851-867

Soetaert K (1989) The genus Desmoscolex (Nematoda, Desmoscolecidae) from a deep-sea transect off Calvi (Corsica, Mediterranean). Hydrobiologia 185:127-143

Soetaert K, Decraemer W (1989) Eight new Tricoma species (Nematoda, Desmoscolecidae) from a deep-sea transect off Calvi (Corsica, Mediterranean). Hydrobiologia 183: 223-247 
Soetaert K, Heip C (1989) The size structure of nematode assemblages along a Mediterranean deep-sea transect. Deep-Sea Res 36:93-102

Soetaert K, Heip C (1995) Nematode assemblages of the deep sea and shelf break sites in the North Atlantic and Mediterranean sea. Mar Ecol Prog Ser 125:171-183

Soetaert K, Vincx M (1987) Six new Richtersia species (nematoda, Selachinematidae) from the Mediterranean Sea. Zool Scr 16(2):125-142

Soetaert K, Vincx M, Heip C (1995) Nematode community structure along a Mediterranean shelf-slope transect. PSZN I: Mar Ecol 16(3):189-206

Soetaert K, Herman PMJ, Middelburg JJ (1996) A model of early diagenetic processes from the shelf to abyssal depths. Geochim Cosmochim Acta 60:1019-1040

Soetaert K, Vanaverbeke J, Heip C, Herman PMJ, Middelburg JJ, Duineveld G, Sandee A (1997) Nematode distribution in ocean margin sediments of the Goban Spur (north-east Atlantic) in relation to sediment geochemistry. Deep-Sea Res 44:1671-1683

Soetaert K, Middelburg J, Wijsman J, Herman P, Heip C (2002) Ocean margin early diagenetic processes and models. In: Wefer G, Billett D, Hebbeln D, Jørgensen BB, von Weesing TJ (eds) Ocean margin systems. Springer Verlag, Berlin, p 157-177

Soltwedel T (2000) Metazoan meiobenthos along continental margins: a review. Prog Oceanogr 46(1):59-84

Soltwedel T, Pfannkuche O, Thiel H (1996) The size structure of deep-sea meiobenthos in the north-eastern Atlantic: nematode size spectra in relation to environmental variables. J Mar Biol Assoc UK 76:327-344

Sommer S, Pfannkuche O (2000) Metazoan meiofauna of the deep Arabian Sea: standing stocks, size spectra and regional variability in relation to monsoon induced enhanced sedimentation regimes of particulate organic matter. Deep-Sea Res II 47(14):2957-2977

Thiel H (1975) The size structure of the deep-sea benthos. Int Rev Ges Hydrobiol 60:575-605

Thiel H (1983) Meiobenthos and nanobenthos of the deep sea. In: Rowe GT (ed) The sea, Vol 8. Wiley \& Sons, New York, p $167-230$

Tietjen JH, Deming JW, Rowe GT, Macko S, Wilke RJ (1989) Meiobenthos of the Hatteras Abyssal Plain and Puerto Rico Trench-abundance, biomass and associations with bacteria and particulate fluxes. Deep-Sea Res I 36:(10) 1567-1577

Editorial responsibility: Otto Kinne (Editor),

Oldendorf/Luhe, Germany
Vanaverbeke J, Soetaert K, Heip C, Vanreusel A (1997a) The meiobenthos along the continental slope of the Goban Spur (NE Atlantic). J Sea Res 38(1-2):93-108

Vanaverbeke J, Arbizu PM, Dalms HU, Schminke HK (1997b) The metazoan meiobenthos along a depth gradient in the Arctic Laptev Sea with special attention to nematode communities. Polar Biol 18:391-401

van der Zee C, van Raaphorst W, Epping E (2001) Absorbed $\mathrm{Mn}^{2+}$ and $\mathrm{Mn}$ redox cycling in Iberian continental margin sediments (northeast Atlantic Ocean). J Mar Res 59(1): 133-166

Vanhove SJ, Wittoeck G, Desmet B, Van den Berghe RL and 7 others (1995) Deep-sea meiofauna community in Antarctica: structure analysis and relation with the environment. Mar Ecol Prog Ser 65:65-76

Vanhove S, Arntz W, Vincx M (1999) Comparative study of the nematode communities on the southeastern Weddell Sea shelf and slope (Antarctica). Mar Ecol Prog Ser 181: $237-256$

Vanreusel A, Vincx M, Bett BJ, Rice AL (1995a) Nematode biomass spectra at two abyssal sites in the NE Atlantic with contrasting food supply. Int Rev Ges Hydrobiol 80: 287-296

Vanreusel A, Vincx M, Schramm D, Van Gansbeke D (1995b) On the vertical distribution of the metazoan meiofauna in shelf break and upper slope habitats of the NE Atlantic. Int Rev Ges Hydrobiol 80:313-326

Vanreusel A, Van den Bossche I, Thiermann F (1997) Freeliving marine nematodes from hydrothermal sediments: similarities with communities from diverse reduced habitats. Mar Ecol Prog Ser 157:207-219

Vanreusel A, Clough L, Jacobsen K, Ambrose W, Jivaluk J, Ryheul V, Herman R, Vincx M (2000) Meiobenthos of the central arctic ocean with special emphasis on the nematode community structure. Deep-Sea Res I 47:1855-1879

Vincx M, Bett BJ, Dinet A, Ferrero T and 5 others (1994) Meiobenthos of the deep Northeast Atlantic. Adv Mar Biol 30:2-87

Wetzel MA, Jensen P, Giere O (1985) Oxygen/sulfide regime and nematode fauna associated with Arenicola marina burrows: new insights in the thiobios case. Mar Biol 124: 301-312

Wollast R (2002) Continental margins - review of geochemical settings. In: Wefer G, Billett D, Hebbeln D, Jørgensen $\mathrm{BB}$, von Weesing $\mathrm{T}$ (eds) Ocean margin systems. Springer Verlag, Berlin, p 15-31

Submitted: July 20, 2001; Accepted: November 27, 2001

Proofs received from author(s): August 30, 2002 